\title{
Navigating the liminal space between childhood and manhood in the Caribbean. How are cultural spaces and physical places divided between the sexes?
}

\author{
David Plummer \\ James Cook University, Australia | david.plummer@jcu.edu.au \\ Stephen Geofroy \\ University of the West Indies, Trinidad and Tobago | stephen.geofroy@sta.uwi.edu \\ Alonso Alvarez \\ Urubamba, Peru | alonso.alvarez.peguero@gmail.com
}

\begin{abstract}
Space is gendered. Private domestic space is classically considered to be a woman's domain while public space is masculine. Of course, men are found in private spaces and women in public, but ownership is a reference to those who typically exercise day-to-day control of that space. It should be remembered, however, that women frequently act as proxies for men in private spaces too; in much of the world, domestic space is inherited by men who are traditionally considered heads-of-the-household. To complicate matters, masculinity comes in many forms and to reconcile these wide variations with narrow, widely-held stereotypes, Connell introduced the term hegemonic masculinity. We take this term as referring to idealised cultural stereotypes related to orthodox masculinity, which provide virtual benchmarks for manhood but which exist nowhere in their absolute form. Nevertheless, these stereotypes serve to map out male domains and they can hence also serve to exclude women, thus making space gendered. We further argue that a potent means of mapping gender domains is through taboos: these taboos designate physical places and cultural spaces that men should not be associated with and doing so can pose grave risks to a reputation and sometimes result in violent retribution. We explore how masculine obligations and taboos construct boundaries between both male and female domains (intergender divides) and create distance between the domains of 'real' men and males who fail to measure up (intragender divides). In particular, we will focus on how the passage to manhood is both deeply affected by, and translates into the everyday character, praxis and ownership of public space with particular reference to manhood in the Caribbean.
\end{abstract}

Keywords: liminal space; childhood; manhood; Caribbean

\section{To cite this article:}

Plummer D., Geofroy S. and Alvarez A. (20I7). Navigating the liminal space between childhood and manhood in the Caribbean. How are cultural spaces and physical places divided between the sexes? The Journal of Public Space, 2(I), 5-I4, DOI: 10.5204/jps.v2il.46

This article has been peer-reviewed and accepted for publication in The Journal of Public Space. Please see the Editorial Policies under the 'About' section of the journal website for further information. 


\section{Introduction}

Spatial metaphors loom large in gender. Take for example terms such as: the gender 'divide', the 'opposite' sex, the masculine 'domain', 'arenas' of masculinity, 'marginalisation' of gender transgression, the 'battleground' for equality 'between' the sexes, and the need to 'create space' for women in the workforce. But spatial considerations are more than just metaphorical when it comes to gender - gender is very much a territorial phenomenon that makes and shapes our social world. At the root of this territorial imperative is a surprisingly simple construct: gender is based on a mutually exclusive binary between masculine and feminine. That is to say for a characteristic to be considered masculine it cannot simultaneously be feminine, at least not in any conventional understanding of gender. As we will show, this mutually exclusive divide profoundly influences the social conventions and rules concerning the distribution and use of space.

\section{Masculinity?}

Unlike biological sex, masculinity is widely acknowledged to be socially constructed and studies have shown that the rules of gender can change, sometimes radically, depending on (i) social context, (ii) cultural differences, and (iii) the passage of time (Gilmore, 1990; Butler, 1999; Zevallos, 20I4). Thus, while masculinity is experienced as solid, fixed and seemingly pre-ordained, there is considerable evidence that this stability is a cultural 'illusion' and under the right circumstances, gender rules can be temporarily suspended and/or permanently shifted. Some researchers (Joyce, 20I3; Coney, 20I5; Booker, 2016) refer to this variability as the 'fluidity' of gender, a phenomenon that has implications for gendered space: as we will see in our discussion of modern schools, custody of space can shift to become common-ground for both sexes (literally no man's land), and in some cases gendered space can 'change hands', for example, professional spaces that were previously considered to be a male domain but are now increasingly dominated by women.

Related to gender fluidity are the many ways that masculinity is enacted in everyday life. These variations depend, for example, on upbringing, cultural context, social class, peer pressure, personal disposition and sexual orientation. For this reason, Connell (1995) argues that it is more accurate to refer to 'masculinities' in the plural rather than using the singular term 'masculinity'. This recognition, that there are many versions of masculinity that can vary by everyday context, cultural difference and across different historical periods, creates a definitional challenge for the term masculinity as it does for gender theory as a whole. In the face of such wide variability, the question is: what actually is 'masculinity'? One way to resolve this conundrum is to propose some universal qualities that transcend this wide variability. An arguably better approach proposed by Connell is the concept of 'hegemonic masculinity' (Connell, 1995), which rather than postulating universal qualities, amounts to a set of aspirational reference points, which are never enacted in absolute terms but which provide benchmarks relating to dominant masculinity against which, men can be measured (Connell, 1995). This approach leaves the possibility open that 'dominant masculinity' can vary in different contexts.

On the other hand, far from rampant fluidity, the gender divide gains considerable inertia from heavy social pressures that obligate us to declare our affiliation with one sex or the other, while simultaneously maintaining a respectable distance from the social territory of 
the opposite sex. This distance arises by means of deep taboos (such as misogyny and homophobia) that demarcate no-go zones, which if transgressed can place a masculine reputation at risk and can sometimes provoke extreme social sanctions, including murder (Plummer, 2005, 2014). Thus, masculinity can be thought of as being a highly variable plural set of masculinities caught in the space between quixotic social expectations and dangerous prohibitions. On one side, are the unrealistic expectations of hegemonic masculinity while, on the other, masculinities are negatively defined by a raft of taboos which designate no-go zones that are off limits for 'real men'. In fact, we would argue that it is the taboos themselves that define hegemonic benchmarks by virtue of being in binary opposition to them: everything a 'real man' should not do or be points to what men should do or be. As discussed elsewhere, these taboos mark powerful social boundaries that are enforced by stigma, shame, loss-of-face and violence (Plummer, 2005, 20I4). These boundaries separate men from women through various taboos related to misogyny (intergender separation) and they separate 'real men' from men who fail to 'measure up' through taboos related to homophobia (intra-gender separation). Thus, gender has spatial metaphors at its core but these have very real consequences.

\section{Masculinity as public performance}

Rather than being a solitary pursuit, masculinity is a collective social enterprise. Manhood is shared with audiences in a way that has many parallels to a stage performance (Butler, 1990). The idea of a stage is useful to keep in mind when we examine the way that masculinities occupy and use public space, but first, let us examine the purpose of the performance and for whom that performance is staged.

First and foremost, gender is a system of social organisation. Gender gains meaning as an organisational code only when it is shared and thereby establishes a common set of social rules. Moreover, as discussed above, masculinity has multiple variants, so repeatedly sharing and performing masculinity has the effect of emphasising and embedding certain dominant gender conventions. Gender performance in everyday life has a number of effects: it makes a public gesture of belonging to a particular sex; it simultaneously affirms separation and distance from the 'opposite' sex both through what that performance valorises and what it deprecates; and it is through these performances that gender boundaries (both inter- and intra-gender) are defined, rehearsed and publicly showcased. Central to this shared set of codes is masculine reputation: a convincing masculine performance can secure a man's reputation while a poor performance (in bed or out) can ruin a man. Costume and props are also fundamental to a convincing performance: stature and physical development help to carry the role off; most clothing styles exhibit pronounced gender dichotomies; features such as the sweat and smell of men and especially the noise generated by men in groups can produce the effect of annexing the space around them; and the accessories they don, whether beer, bling or scars are worn like masculine badges of honour.

But if masculinity is a performance, then who is the intended audience? In one sense the performance is for society-at-large, given that codes of masculine obligation and taboo are being enacted in order to gain social approval and to shore up one's reputation. In another sense the audience is more immediate. While it is reasonable to assume that the primary audience for masculine performance is the opposite sex, arguably an equal, if not more important audience is his male peers. For a young man, the peer group is central to 
his successful passage from childhood to manhood (Mac an Ghaill, 1994). The group provides a forum for rehearsing masculinities, scrutinising his performance, providing critical feedback and the group will police and, if necessary, enforce the standards of masculinity that they revere.

\section{The passage to manhood}

The key gendered space that needs unpacking is a liminal one. This space is both a vehicle and a passage between two worlds: specifically, the passage between the worlds of childhood and manhood. In modern physical terms, this transformative space is largely located in and around the school ground, but in the past things were different. Many, probably all, traditional societies attached high importance to the achievement of manhood. Yet, as we noted earlier, masculinity can be fluid, which may well explain why so many cultures developed elaborate rules and practices governing this transition. These arrangements have been referred to as 'rites of passage' (Van Gennep, 1960: ix, 67). These rites served to ensure that the passage was successful and that a socially mandated version of manhood was adopted. Van Gennep divided passage into 3 phases: separation from the former self; transition in a liminal state; and incorporation into a new status. While these rituals varied widely, several characteristics were frequently present. First, rather than taking place in full public view, many of the rites were secretive and involved the seclusion of the boys undergoing transition. In keeping with the ambivalent, liminal nature of the passage and depending on your gendered perspective these ritualised spaces could either be considered private because women were excluded or public because they constituted important collective men's business. Second, these rites usually involved transitioning as a member of a group of peers who were all becoming men at the same time. Third, the rites were orchestrated and supervised by senior men in the community, in what we will call vertical mentoring; that is to say, mentoring by the generation above (DuBois \& Karcher, 2005). Fourth, it was not uncommon for the rites to require boys to complete a ritualised challenge to publicly 'prove' their manhood. On occasion, this challenge could be difficult, painful and/or dangerous (Crichlow, 2004).

The traditional rites of passage outlined above, when contrasted with modern adolescence, can be useful for understanding masculinities in the Caribbean - an area in which we have researched (Plummer, McLean, Simpson, 2008; Plummer, 2009; Plummer \& Geofroy, 2010; Plummer, 2013). In Anglophone Caribbean countries, there is clear and sustained evidence of shifting gender arrangements, a shift that has transpired over several decades. This shift is particularly apparent in the education sector where there has been a steady decline in school completion by boys and a concurrent growth in the proportion of girls graduating (Chevannes, 1999). This effect is highly evident in tertiary education too. The University of the West Indies, which has major campuses in Jamaica, Barbados and Trinidad and minor campuses in many other regional countries, has experienced a consistent decline in enrolment and completion by young men over the last few decades (Figueroa 2004, I4I; Reddock, 2004; UWI, 2010). Some researchers refer to this process as the 'feminisation' of schooling (Haywood, Popoviciu, Mac An Ghail, 2005), however this terminology has unfortunate connotations in that it can be taken to imply that women and girls are to blame for boys' failures and devalues the important progress made in education by Caribbean women (Miller, 1986). In our opinion, a more constructive descriptor is the 'de-masculinisation' of schooling (Arnot \& Mac an Ghaill, 
2005). A key feature of this phenomenon is that boys are walking away from education, as are men from teaching. We argue that this shift can be traced to changes in the passage to manhood in these countries (and for that matter similar trends elsewhere). With increasing development and growing populations in parts of the Caribbean, people's lives are being transformed. Life in villages and small communities is being overtaken; by urbanisation, lengthy and congested commuting, and economic imperatives that require both men and women to work. While there is nothing inherently wrong with these changes, they do have implications for how boys undertake their journey to manhood, primarily because of reduced opportunities to benefit from role models and vertical mentoring. Despite widespread social change, including in gender arrangements, achieving manhood is as important as it ever was for boys. It remains very difficult, if not impossible, for young people to grow-up 'gender neutral' or to transition to become a member of the opposite sex and for all intents and purposes, becoming a man is compulsory (Plummer, 20I4). Yet, becoming a man is a complex process and as we have seen this seemingly natural process is by no means automatic. In Gilmore's words (1990: 25), 'Boys have to be encouraged, sometimes actually forced, by social sanctions to undertake efforts toward a culturally defined manhood, which by themselves they might not do.'

So, with the decline of traditional forms of rites of passage, the question then arises: how do boys navigate their way to manhood now? We believe part of the answer lies in the school ground. With the rise of modern education, the ritual space previously occupied by traditional rites of passage was subsumed into the school years. We argue that van Gennep's three stage process of separation, transition and incorporation has parallels in separation on the first day at school, a somewhat protracted transition in the company of peers during the school years, and subsequent incorporation into the adult world on completion of schooling (Plummer \& Geofroy, 20I0). Thus, with the rise of modern education, the school became a primary site for establishing masculine credentials and transitioning to adulthood (Messerschmidt, 1994, Pascoe, 2007). However, these developments did not end here. Subsequent social changes have had further major impacts on the journey to modern manhood. First, schooling ceased to be regarded as the sole privilege of boys and second, opportunities for men from older generations to mentor boys in the transition to manhood were curtailed (for example, through work pressures, fewer male teachers and moral panic about men leading youth groups; see also Lewis, 2008). As schooling evolved, education was opened up to girls (as, of course, it should be) and the classroom became a place of equal opportunity.

An unanticipated consequence of these changes was that academic prowess started to lose its utility as a way for boys to establish their masculine credentials - the classroom no longer offered a substitute space for the modern rites of passage. Yet, as we noted, achieving manhood continues to be as important as ever, and boys needed new ways to navigate this difficult transition. Furthermore, if the adult world was not going to provide the means, boys increasingly had to take matters into their own hands. With growing equality in educational opportunities, the primary remaining means of differentiating between the sexes was physical development. The focus shifted to physical differences and physical performance in what has elsewhere been called a 'retreat to the body' (Plummer, McLean, Simpson, 2008; Plummer, 2013, 2016). The utility of the classroom declined, but the school ground continued to be fairly sex-segregated and physical spaces assumed growing importance for rites relating to manhood. Relocation of the rites to the 
school ground and the reduced involvement of older men shifted the emphasis away from vertical mentoring and the resulting vacuum became occupied by peer groups and 'horizontal mentoring' (Plummer \& Geofroy, 2010: 14; see also Lewis, 2008). The growing importance of peer-based (horizontal) mentoring and the 'retreat to the body' as a means of securing gender identity through more certain physical means, while effective in many cases, was not without problems. First, the prevailing standards of masculinity became those of peers, not necessarily those of the external world and of older, more experienced and hopefully wiser men. Second, the focus on physicality inevitably gave precedence to physical power, which enhanced the authority and status of stronger and more aggressive peers - a process referred to elsewhere as the 'rise of hard masculinity' (Plummer, McLean \& Simpson, 2008: 9; Plummer, 2010). These changes left other members of the school community subject to the laws of the adolescent 'jungle' and had the potential to be very disruptive. At the extreme, peer groups themselves promulgated the prevailing masculine codes, which they also policed and enforced, sometimes brutally. Group membership was often determined by a boy's willingness to take risks, not unlike the old ritual challenges. Risk was readily equated with masculine qualities of strength and bravery and was used as a public means of 'proving' manhood and qualifying for membership of the group. Sometimes these risks could be dangerous, including robbery, violence and murder. And while the outside world might see these acts as deeply antisocial and threatening, the boys themselves experience them as a fulfilment of their social obligations to the culture they know and to those who matter most, their peers. Refusal to collaborate with these methods or backing out of such a challenge is risky in itself because it suggests a lack of masculinity, which is both transgressive and taboo. This drive for masculine status coupled with the taboos associated with failure had the capacity to push some groups towards dangerous and antisocial hyper-masculine acting-out, with few if any circuit breakers.

A further consequence of the 'retreat to the body' in a binary system is a reciprocal deprecation of the classroom as being a site that contributes little or nothing to building a masculine reputation - indeed too much classroom education could even be seen as soft and emasculating. Unlike physical accomplishments, trying hard in class and demonstrating academic prowess appears to have become increasingly stigmatised and boys who were good in class regularly reported misogynistic and homophobic criticism. To the contrary, it was important to seem disinterested during lessons; to speak in a localised creole accent rather than polished English (Campbell, 20I3); not to be too neat or tidy; to avoid being favoured by teachers; and not to come over as too conscientious or adept in academic matters (Plummer, McLean \& Simpson, 2008: 9). In Trinidad, accounts were provided by boys who hid their academic achievements from their peers, including some who tried to fail their exams in order to live up to peer group expectations and to avoid persecution (Plummer \& Geofroy, 2010). These dynamics played out differently depending on access to private and public space. Boys from poor settings typically grew up in crowded houses with few rooms and much of their development was done in public spaces such as the streets, street corners and shopping malls. There were few opportunities to escape the keen eye of the peer group and very little private space in which to avoid scrutiny and to study undetected. In contrast boys who grew up in more affluent settings were more easily able to evade the peer group and take advantage of greater amounts of private space in order to pursue their academic priorities. In Trinidad

10 | The Journal of Public Space, 2(I), 20I7| ISSN 2206-9658

(C) Queensland University of Technology 
and Tobago, there was evidence that the situation may have been exacerbated by the introduction of 'shift schooling', which was intended to ensure that children had universal access to education. However, while most young people spent half their day at school, the rest of the day was often spent without adult supervision in the company of their peers on the streets. Moreover, in Jamaica, we found evidence that public transport by minibus to and from school was influential. In order to gain competitive advantage, some of these minibuses were 'pimped out' and played loud music, including music that was notoriously sexist and violent (see Stop Murder Music, 2004). Many schoolboys considered these buses to be 'cool' and preferred to be seen travelling on them as a way of 'enhancing' their image of being a 'bad boy'.

\section{On territories, barrios, battlegrounds, venues, stages and arenas}

By now, you may well be thinking that the developments described above seem very similar to gang lore. If so, we would agree and further suggest that the main differences between a peer group and a gang are 'a matter of degree' and that a gang ultimately spills over into another public space, the streets (Plummer \& Geofroy, 2010: 14). The above account of the passage to manhood in the West Indies is by no means universal nor is it the same for all boys. However, it does set the scene for understanding how masculinity might define and commandeer public space in the world beyond the school ground too. Indeed, it is apparent from the discussion that the division between the school ground and the outside world, while useful, is porous and arbitrary. In many senses the streets are an extension of the school ground and vice versa. The main point is that the transition from childhood to manhood is where the ground rules are laid down and that these find their way into society on graduation. This is the reverse of what is commonly assumed that boys internalise the rules from wider society. Indeed, there is almost certainly a balance in both directions: with 'balance' being the important consideration. It is, however, prudent to recall the work on cultivation of male identity in Jamaica by the prominent Caribbean researcher Barry Chevannes (1999) where he argued that we reap what we sow.

Caribbean English has a word for socialising or relaxing which often includes spending time idly on the street: the word is 'liming' (Allsopp, 1996: 349; Winer, 2009: 531). Liming is a popular and well-known pastime, culturally important and often mentioned with fondness. Liming is a reminder of the importance of street life and as we saw in the preceding section young people from the school years have ample opportunity to lime on the streets - indeed young people from poorer backgrounds often have little choice and do much of their growing up on the block, the streets, street corners and in shopping malls. While not necessarily bad, socialising on the streets while growing up is not always trouble free. As we have seen, peer groups can extend their domain onto the streets and with the associated emphasis on physicality and risk-taking, the 'retreat to the body', the rise of 'hard masculinity' and growing influence of horizontal rites of passage, the peer group is susceptible to morphing into a gang. The implications for public space are well known: at their most extreme, gangs have territories, are armed and can engage in violent conflict. In Jamaica, these territories - or garrison communities - can take on the characteristics of a fiefdom ruled over by a 'Don' whose enforcers are called 'shotters'. There is hardly a better example of public space where masculinity is writ large. But these 
public spaces are not uniformly public: there are insiders and outsiders and that is perhaps the point of a so-called Garrison community arrangement.

But it would be a distortion and do an injustice to the region to simply focus on gangs and garrison communities. Likewise, it would be a misrepresentation of masculinities to only see them in a negative light. There are many positive examples of diverse masculinities in the region, not least are the great authors and musical wordsmiths, which also have their own impact on public space. Masculinities both positive and negative feature prominently in the diverse musical traditions of the Caribbean. The works of Bob Marley and his fellow Jamaican musicians and the Calypso traditions from Trinidad are both deeply steeped in both sexuality and gender not to mention crucially important social criticism (Rohlehr, 1990). It is in these traditions that gender is most literally brought to the public stage. At certain times of the year, during Carnival season, whole countries are turned into stages where gender roles are both writ large and the rules are torn up. For the remainder of the year when Carnival sounds fade into the background (but never entirely disappear), men return to their other stages - not least being the pulpit - representing aspects of Caribbean existence in communities characterised by religion and conservative ideology.

\section{Conclusion}

This paper raises the issue of the social geography of masculinity in the Caribbean. We explored fundamentally sensitive gender roles while highlighting shifts in the gendered meanings ascribed to particular public spaces - in this case the rites of passage and the school - providing analytic perspective into important social phenomena in the Caribbean and wider implications for understanding the gendered nature of space. What is also clear is that these changes are reciprocal in that public spaces are very susceptible being colonised by gender codes and practices. We also argue that in gender terms, public space is multidimensional. It is a highly-interconnected blend of physical, visual, auditory, linguistic, musical, tactile, olfactory, emotional, risky, dangerous, and, of course, pleasurable cultural spaces. Gender is territory, both metaphorical and physical. Metaphorical because it is first and foremost a conceptual divide between categories of people that creates an almost insurmountable cultural distance; but nevertheless, this metaphorical separation has very real physical consequences.

\section{References}

Allsopp, R. (1996). Dictionary of Caribbean English usage. Kingston, Jamaica: University of the West Indies Press.

Arnot, M., \& Mac an Ghaill, M, (2006). (Re) contextualizing gender studies in education. In M. Arnot \& M. Mac an Ghaill (eds.) The RoutledgeFalmer Reader in Gender \& Education. New York, NY: Routledge.

Bailey, W., C. Branche, and A. Henry-Lee (2002). Gender, contest and conflict in the Caribbean. Mona, Jamaica: Sir Arthur Lewis Institute of Social and Economic Research (SALISES).

Booker, L. (2016). What it means to be gender-fluid. Retrieved from: http://edition.cnn.com/2016/04//3/living/gender-fluid-feat/

Butler, J. (1990). Gender Trouble: Feminism and the Subversion of Identity. New York, NY: Routledge. 
Campbell, W. (2013). We need to rescue our boys. Jamaica Observer. Retrieved from: http://www.jamaicaobserver.com/mobile/columns/We-need-to-rescue-our-boys 137|397|

Chevannes, B. (1999). What we sow and what we reap-problems in the cultivation of male identity in Jamaica. Kingston, Jamaica: Grace Kennedy Foundation.

Coney, N. (20I5). Performing Genders: A Study of Gender Fluidity. From: http://digitalcommons.linfield.edu/cgi/viewcontent.cgi?article $=1008 \&$ context $=$ soanstud theses

Connell RW (1995), Masculinities. Sydney: Allen and Unwin.

Crichlow, W. E. A. (2004). History, (Re)memory, testimony and biomythography: charting a buller Man's Trinidadian past. In R. E. Reddock (ed.), Interrogating Caribbean masculinities (pp. I85222). Mona, Jamaica: University of the West Indies Press.

DuBois, D. and M. Karcher. 2005. Handbook of youth mentoring. London: Sage Publications.

Figueroa, M. (2004). Male privileging and male academic underperformance in Jamaica. In R. E. Reddock (Ed.), Interrogating Caribbean masculinities. Mona, Jamaica: University of the West Indies Press.

Gilmore, D.D. (1990). Manhood in the Making. New Haven: Yale University Press.

Haywood, C., Popoviciu, L., Mac An Ghaill, M. (2005). Feminisation and schooling: Remasculinisation, gendered reflexivity and boyness. Irish Journal of Sociology. 14(2), $193-212$.

Joyce, R. (2013). Where a Gender Spectrum May Be Taking Us. Retrieved from Psychology today website: https://www.psychologytoday.com/blog/what-makes-us-human/201307/where-genderspectrum-may-be-taking-us

Lewis, T. (2008). No Role Models for Black Youths. Trinidad and Tobago Express, July 5, 2008.

Mac an Ghaill, M. (1994). The making of men. Buckingham: Open University Press.

Messerschmidt, James W. (1994). Schooling, Masculinities and Youth Crime by White Boys. In Just Boys Doing Business: Men, Masculinities and Crime, edited by Tim Newburn and Elizabeth A. Stanko, 8I-99. London: Routledge.

Miller, E. (1986). The Marginalization of the Black Male: Insights from the Development of the Teaching Profession. Kingston, Jamaica: Institute of Social and Economic Research.

Parry, O. (2004). Masculinities, myths and educational under-achievement: Jamaica, Barbados and St Vincent \& the Grenadines. In: Interrogating Caribbean masculinities ed. R. E. Reddock. Mona, Jamaica: University of the West Indies.

Pascoe, C.J. (2007). Dude you're a fag. Berkeley, CA: The Regents of the University of California.

Plummer, D. (2005). Crimes against manhood: homophobia as the penalty for betraying hegemonic masculinity. In: Perspectives in human sexuality, eds. G. Hawkes and J. Scott. Melbourne, Australia: Oxford University Press.

Plummer D. (2009). How risk and vulnerability become 'socially embedded': insights into the resilient gap between awareness and safety in HIV. In: Barrow C, de Bruin M, Carr R. Sexuality, Social exclusion \& human rights: vulnerability in the Caribbean context of HIV. Kingston: lan Randall Publishing.

Plummer, D. (20I0). Is learning becoming taboo for Caribbean boys? In: Morrissey, Michael, Bernard, Myrna, and Bundy, Donald, (eds.) Challenging HIV \& AIDS: a new role for Caribbean education. Paris, France: UNESCO) and lan Randle Publishers.

Plummer D. (2013). Masculinity and risk: how gender constructs drive sexual risks in the Caribbean. Sexuality Research and Social Policy. 10(3): I65-174. DOI: 10.1007/s I3 I78-0 I3-0I I6-7.

Plummer, D. (20I4). The ebb and flow of homophobia: a gender taboo theory. Sex Roles, 7I (3-4), I26-136.

Plummer, D. (2014). Masculinity and terror - The missing conversation. Retrieved from The Conversation website: https://theconversation.com/masculinity-and-terror-the-missingconversation-32276

Plummer, D. (2016). Boys' Peer Cultures. In: The Wiley Blackwell Encyclopedia of Gender and Sexuality Studies. I-3. 
Plummer D., Geofroy S. (20I0). When bad is cool: violence and crime as rites of passage to manhood. Caribbean Review of Gender Studies, 4

(http://www2.sta.uwi.edu/crgs/february2010/journals/PlummerGeofory.pdf).

Plummer D., McLean A., Simpson J. (2008). Has learning become taboo and is risk-taking compulsory for Caribbean boys? Caribbean Review of Gender Studies, 2 (http://sta.uwi.edu/crgs/september2008/journals/DPlummerAMclean/Simpson.pdf).

Reddock, R. (ed.). (2004). Interrogating Caribbean Masculinities. Mona, Jamaica: University of the West Indies Press.

Rohlehr, G. (1990). Calypso \& society in pre-independence Trinidad. Port-of-Spain, Trinidad and Tobago.

Stop Murder Music (2004). Dancehall Dossier. Outrage! Retrieved from http://outrage.org.uk/wpcontent/uploads/2010/05/Dancehall-Dossier-FULL.pdf.

UWI (2010). Statistical Review: Academic Year 2009/2010. Mona, Jamaica: University of the West Indies. Retrieved from https://www.mona.uwi.edu/opair/statistics/

Van Gennep, A. (1960). (French original edition 1908). The rites of passage. Chicago: University of Chicago Press.

Winer, L. (2009). Dictionary of the English/Creole of Trinidad \& Tobago: On Historical Principles. Montreal: McGill-Queen's University Press.

Zevallos, Z. (2014). Sociology of Gender. Retrieved from website The Other Sociologist https://othersociologist.com/sociology-of-gender/ 